\title{
Antimicrobial Evaluation of Trisubstituted 2-piperazinyl Thiazoles
}

\author{
Betül Giray ${ }^{1 *}$, Leyla Yurttaş², Zafer Şahin ${ }^{3}$, Barkın Berk ${ }^{3}$, Şeref Demirayak ${ }^{3}$ \\ 1 Istanbul Medipol University, School of Medicine, Department of Pharmaceutical Microbiology, 34083 İstanbul, Turkey. \\ 2 Anadolu Üniversitesi, Faculty of Pharmacy, Department of Pharmaceutical Chemistry, 26470 Eskişehir, Turkey. \\ 3 Istanbul Medipol University, School of Pharmacy, Department of Pharmaceutical Chemistry, 34083 İstanbul, Turkey.
}

\begin{abstract}
Thiazole and basic nitrogen containing rings are important chemical moieties of antimicrobial drugs. In recent, third generation cephalosporins include thiazole ring system. In this study, we synthesized 33 piperazine thiazole derivatives which were thought to show antimicrobial activity. Synthesize were realized with good yield using the method which reports the anticholinesterase properties of these compounds. Similar compounds with the same scaffold $(2,4,5$ trisubstituted thiazoles) are investigated for antimicrobial activity. Compounds 23-27 exhibited MIC: $256 \mu \mathrm{M}$ against $S$. aureus ATCC 25923. Besides, 27-33 group showed MIC: $256 \mu \mathrm{M}$ against $K$. pneumoniae $\mathrm{UC} 57$ and $B$. cereus. It is remarkable that the compound $\mathbf{2 7}$ showed antimicrobial activity against 4 different microorganisms and $\mathbf{2 6}$ showed antimicrobial activity against $L$. monocytogenes by MIC: $32 \mu \mathrm{M}$ which is same as the standart chloramphenicol.
\end{abstract}

Keywords: thiazole, piperazine, antimicrobial, trisubstituted thiazole, N-benzoylthioamide.

\section{INTRODUCTION}

Bacterial resistance to the treatment of infectious diseases is the main problem. Many classes of antibiotics are facing resistance and have initiated new efforts to develop new derivatives and discover new chemical classes. ${ }^{1}$ Gram positive and gram-negative bacteria such as Escherichia coli, Staphylococcus aureus, Micrococcus luteus, Bacillus subtilis, Bacillus cereus, Pseudomonas aeruginosa etc. are responsible for many diverse infections which even can cause of death. ${ }^{2}$ Thiazole and basic nitrogen containing rings are important chemical moieties of antimicrobial drugs. Recently, third generation cefepime, ceftriaxone, cefix-

*Corresponding Author: Betül Giray, e-mail: bgiray@medipol.edu.tr (Received 03 December 2018, accepted 23 December 2018) 
ime, ceftazimide drugs are wide spectrum cephalosporins containing thiazole ring system. Also, new studies on compounds with thiazole moiety are investigated. ${ }^{3-5}$ List of the synthesized compounds, which were first evaluated for their acetylcholinesterase inhibitor activity by our group ${ }^{6}$ is given in Table 1 .

Table 1. Synthesized compounds

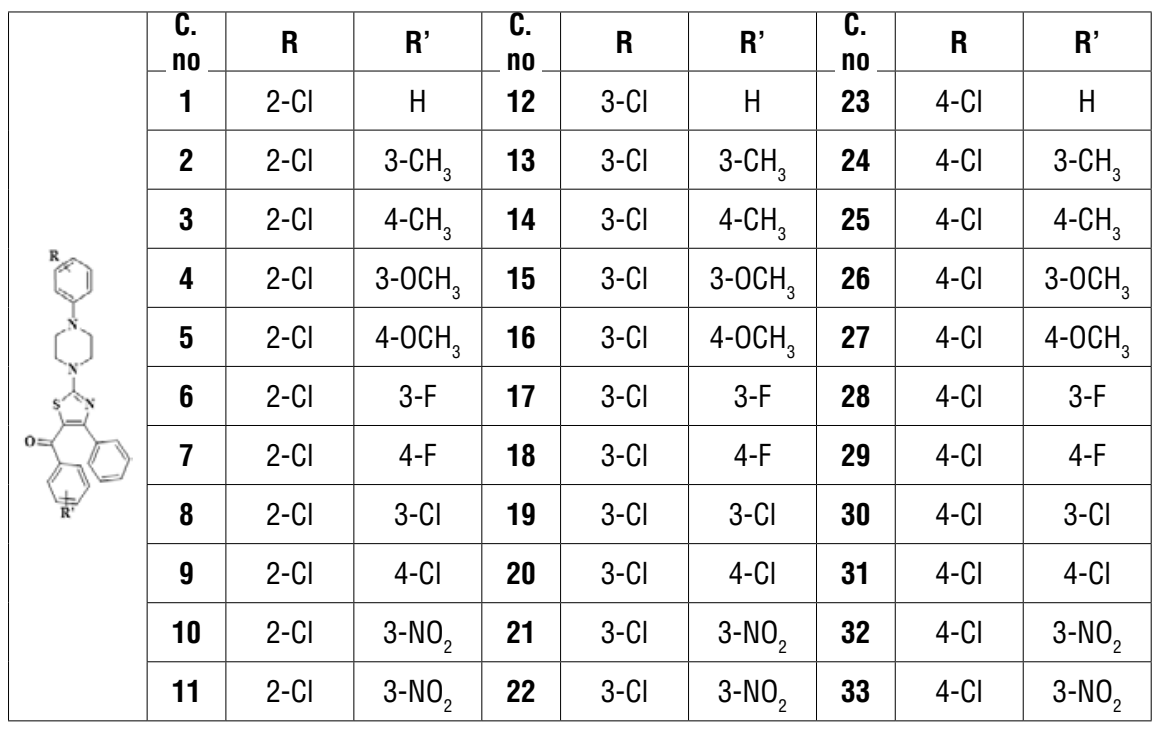

Similar compounds with the same scaffold (2, 4, 5 trisubstituted thiazoles) are investigated for antimicrobial activity. These compounds also have the same substituents on the thiazole ring such as piperazine (morpholine) at 2nd position, phenyl at 4 th position and benzoyl at 5 th position.

As a pioneer of this study, 2, 4, 5-trisubstituted thiazole derivatives (I) were screened for antimicrobial activity against $E$. coli, S. aureus, M. luteus, B. subtilis, $B$. cereus, $P$. aeruginosa bacterial strains by paper disc diffusion method. In this study, all 7 compounds showed moderate to good activity. According to zone diameters, activity was found approximately \%40-45 of ciprofloxacin. ${ }^{7}$ 
<smiles>COc1ccc(OC)c(C(=O)c2sc(N3CCOCC3)nc2-c2ccccc2)c1</smiles>

Darji et al. 2012a

I

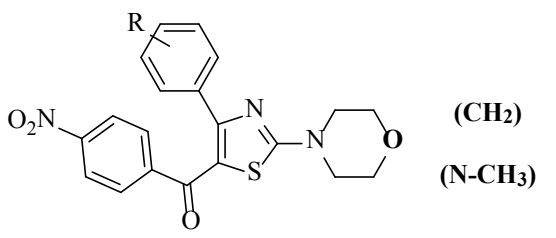

Darji et al. 2012b

II

Figure 1. Trisubstituted thiazole compounds with antimicrobial activity

In another study of the same group, similar compounds (II) were evaluated for antimicrobial activity against same strains. 7 of 8 compounds exhibited good activity, which was very close to standard ciprofloxacin. ${ }^{8}$

In this study, we synthesized 33 compounds, which are thought to show antimicrobial activity. Synthesize were realized with good yield using the method which reports the anticholinesterase activity of these compounds. ${ }^{6}$

\section{METHODOLOGY}

\section{Chemistry}

Synthesis of 33 compounds were carried out by the method used in a recent study. ${ }^{6}$ Following the method, N'-benzoyl piperazine thioureas (10 mmol) and bromoacetophenones (10 $\mathrm{mmol}$ ) reacted to give the compounds. The equivalent mole of materials was boiled in ethyl alcohol until the reaction was being completed. After cooling, it was poured into the water and neutralized with $\mathrm{NaHCO}_{3}$ solution. The products were crystallized from ethanol. ${ }^{6,9}$

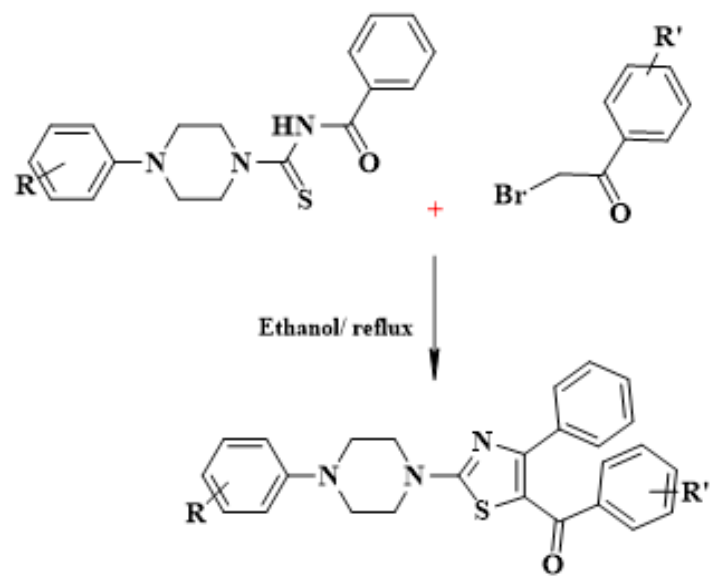

Scheme 1. Synthesis of compounds 


\section{Antimicrobial Activity Test}

Antimicrobial activity test was determined on both gram positive and gramnegative bacteria strains including, Escherichia coli ATCC 25922, Klebsiella pneumonia UC57, Enterococcus faecalis ATCC 29212, Listeria monocytogenes ATCC 7644, Salmonella typhi ATCC 19430, Pseudomonas aeriginosa ATCC 27853, Staphylococcus aureus ATCC 25923, Bacillus cereus ATCC 7064, Listeria monocytogenes ATCC 7644. Clinically isolated Acinetobacter baumannii and Shigella dysenteria were provided by Hospital of İstanbul Medipol University. All these compounds were dissolved in DMSO to prepare stock solution at $10 \mathrm{mg} / \mathrm{mL}$. Broth microdilution method was carried out in accordance with the relevant 2012 CLSI standard. ${ }^{10,11}$ The bacterial strains were inoculated and grown to mid-log phase in Muller Hinton Broth (MHB) at 37 degrees. Bacterial inoculum suspensions were prepared at a final concentration of approximately 1 x105 cfu/ml. Materials were 2-fold serially diluted to make different concentration, from 0.5 to 256 micromolar. Equal volumes of inoculum suspensions were than added to each well of sterile 96 well-plate with different concentration of materials, and the plate was incubated $18 \mathrm{~h}$ at $37^{\circ} \mathrm{C}$. Positive or negative control were set to wells with and without bacteria, respectively. Besides, chloramphenicol is used as positive control. MIC was defined as the lowest concentration of materials that prevented visible turbitidy by visual inspection. Experiments were performed duplicate.

\section{RESULTS}

\section{Chemistry}

Synthesis of compounds were carried out up to \%80 yield. Characterizations were corresponded our previous study IR, ${ }^{1} \mathrm{H}-\mathrm{NMR}$ and ${ }^{13} \mathrm{C}-\mathrm{NMR}$ results were previously reported in the related paper. ${ }^{6}$

\section{Antimicrobial activity}

No antimicrobial activity was detected against $E$. coli, S. Typhii, P. aeriginosa, $S$. dysanteria ve A. Baumanni bacteria. Activity on the other bacteria is summarized in Table 2.

27-33 compound series against $K$. pneumoniae and B. Cereus microorganisms are effective. It is important that these compounds are effective against two different microorganisms in serials. When the whole table was examined, the compounds in the range 23-33 were found to be effective against to the microorganisms. This indicates that the 4-chlorophenyl structure attached to the piperazine ring is beneficial for antimicrobial activity. The structures in 
the 23-27 group against $S$. aureus have been found effective. In this group, electron donating substituents (R') were prominent. 13, 17, 27, 31 (MIC: 256 $\mu \mathrm{M}$ ), 32 (MIC: $128 \mu \mathrm{M}$ ), 33 (MIC: $64 \mu \mathrm{M}$ ) effects have been found against $E$. facealis. Chloramphenicol has no effect on this microorganism.

Table 2. MIC of te materials against bacteria.

\begin{tabular}{|c|c|c|c|c|c|}
\hline \multirow[b]{2}{*}{ Compounds } & \multicolumn{4}{|c|}{ MIC $(\mu \mathrm{M})$} & \multirow[b]{2}{*}{$\begin{array}{l}\text { L. monocyto- } \\
\text { genes ATCC } 764\end{array}$} \\
\hline & $\begin{array}{l}\text { K. pneumoniae } \\
\text { UC57 }\end{array}$ & $\begin{array}{l}\text { S. aureus ATCC } \\
25923\end{array}$ & $\begin{array}{c}\text { E. faecalis ATCC } \\
29212\end{array}$ & B. cereus & \\
\hline 1 & - & - & - & - & - \\
\hline 2 & - & - & - & - & - \\
\hline 3 & - & - & - & $\geq 256$ & - \\
\hline 4 & - & - & - & - & - \\
\hline 5 & - & - & - & - & - \\
\hline 6 & - & - & - & - & - \\
\hline 7 & - & - & - & - & - \\
\hline 8 & - & - & - & - & - \\
\hline 9 & - & - & - & - & - \\
\hline 10 & - & - & - & - & - \\
\hline 11 & - & - & - & - & - \\
\hline 12 & - & - & - & - & - \\
\hline 13 & - & - & $\geq 256$ & - & - \\
\hline 14 & - & - & - & - & - \\
\hline 15 & - & - & - & - & - \\
\hline 16 & - & - & - & - & - \\
\hline 17 & - & - & $\geq 256$ & - & - \\
\hline 18 & - & - & - & - & - \\
\hline 19 & - & - & - & - & - \\
\hline 20 & - & - & - & - & - \\
\hline 21 & - & - & - & $\geq 256$ & - \\
\hline 22 & - & - & - & - & $\geq 256$ \\
\hline 23 & - & $\geq 256$ & - & - & - \\
\hline 24 & - & $\geq 256$ & - & $\geq 256$ & - \\
\hline 25 & - & $\geq 256$ & - & - & - \\
\hline 26 & - & $\geq 256$ & - & - & $\geq 32$ \\
\hline 27 & $\geq 256$ & $\geq 256$ & $\geq 256$ & $\geq 256$ & - \\
\hline 28 & $\geq 256$ & - & - & $\geq 256$ & - \\
\hline 29 & $\geq 256$ & - & - & $\geq 256$ & - \\
\hline 30 & $\geq 256$ & - & - & $\geq 256$ & - \\
\hline 31 & $\geq 256$ & - & $\geq 256$ & $\geq 256$ & - \\
\hline 32 & $\geq 256$ & - & $\geq 128$ & $\geq 256$ & - \\
\hline 33 & $\geq 256$ & - & $\geq 64$ & $\geq 256$ & - \\
\hline Chloramphenicol & $\geq 256$ & $\geq 256$ & - & $\geq 32$ & $\geq 32$ \\
\hline
\end{tabular}


Against L. monocytogenes, compounds 22 (MIC: $256 \mu \mathrm{M}$ ) and 26 (MIC: $32 \mu \mathrm{M}$ ) were found active. Although it is not appropriate to make a chemical interpretation here, the activity of compound 26 is the same as the standard compound chloramphenicol.

\section{CONCLUSION}

Compound 27 has effect on 4 of 5 microorganisms with 256 MIC values. Besides, 27-33 has $256 \mu \mathrm{M}$ MIC value against $K$. pneumoniae and B. cereus as series. This empowers the idea that activity is related to chemical structure. Furthermore 23-27 on S. aureus has antimicrobial effect as a chemical series. These results can be associated with the chemical structure and efforts can be continued in these chemical groups for investigating new antimicrobial drugs.

\section{REFERENCES}

1. Levy, S.B.; Marshall, B.; Antibacterial resistance worldwide: causes, challenges and responses. Nat Med. 2004, 10, 122-129.

2. Seifert, S.; Dirita V. Evolution of microbial pathogens, ASM Press, Washington, (2006).

3. Holla, B.S.; Karthikeyan, M.S.; Prasad, D.J.; Mahalinga, M.; Kumari, N.S.; Synthesis of some novel 2, 4-disubstituted thiazoles as possible antimicrobial agents, Eur. J. Med. Chem. 2008, 43, 261-267.

4. Holla, B.S.; Malini, K.V.; Rao, B.S.; Sarojini, B.K.; Kumari, N.S.; Synthesis of some new 2, 4-disubstituted thiazoles as possible antibacterial and anti-inflammatory agents, Eur. J. Med. Chem. 2oo3, 38 (3), 313-318.

5. Sarojini, B.K.; Darshanraj, C.G.; Bharath, B.R.; Manjunatha, H. Synthesis, characterization, in vitro and molecular docking studies of new 2, 5-dichloro thienyl substituted thiazole derivatives for antimicrobial properties, Eur. J. Med. Chem. 2010, 45 (8), 3490-3496.

6. Sahin, Z.; Ertas, M.; Bender, C., Bulbul, E. F., Berk, B., Biltekin, S. N., Yurttas, L., Demirayak, S. Thiazole-substituted benzoylpiperazine derivatives as acetylcholinesterase inhibitors. Drug Dev Res. 2018, 79, 406-425.

7. Darji D.N.; Pasha T.Y.; Bhandari, A.; Molvi, K.I.; Desai, S.A.; Makwana, M.V. Synthesis and Spectral characterization of some novel (2, 5-dimethoxyphenyl)-(2,4-disubstituted-thiazol5-yl) methanone as possible antibacterial agents, Der Pharma Chemica. 2012, 4(2), 808-812.

8. Darji D.N.; Pasha T.Y.; Bhandari, A.; Molvi, K.I.; Desai, S.A.; Makwana, M.V. Synthesis of some novel 2, 4, 5 -trisubstituted thiazoles as possible antibacterial agents. J. Chem. Pharm. Res. 2012, 4(4), 2148-2152.

9. Ried, W.K.; L. Neuartige Synthese substituierter 2-Morpholino- und 2-Athox ythiazole. Liebigs. Ann. Chem. 1976, 395-399.

10. Balouriri, M.; Sadiki, M.; Ibnsouda S. K. Methods for in vitro evaluating antimicrobial activity: A review. J. Pharm. Anal. 2016, 6(2) 71-79.

11. Cockerill et al., CLSI, Methods for Dilution Antimicrobial Susceptibility Tests for Bacteria That Grow Aerobically, Approved Standard, 7th ed., CLSI document M7- A7 Clinical and Laboratory Standart Institute, 950 West Valley Road, Suite 2500, Wayne, Pennsylvania 19087, USA 2012. 